\title{
WAR WORK IN VOCATIONAL EDUCATION
}

\author{
By C. A. Prosser, \\ Director of the Federal Board for Vocational Education.
}

As the law provides they shall be, the activities of the Federal Board for Vocational Education are largely coöperative. This board administers federal grants in aid of vocational education in the states, and it is at present largely engaged in providing emergency war training for conscripted men, and in organizing for undertaking national reëducation and return to civil employment of men disabled in the war.

Federal grants become available each year, in amounts increasing from approximately $\$ 1,650,000$ in $1917-18$, to $\$ 7,160,000$ in 1925-26 and annually thereafter, and if accepted by the states the federal grants must be matched by equal amounts of state money. In the past ten months, since the board organized, all of the states without exception have accepted grants, matching federal with state money to be expended for promoting vocational education in the public schools throughout the country.

It is a rare event when our sovereign states elect unanimously to take any single course even when their own best interests point the way clearly, and the event of the forty-eight states taking unanimous action involving expenditure of state money within a brief period of ten months under a permissive federal statute is unique in our history. It is in itself conclusive proof that the federal law in this instance has been wisely conceived by Congress to insure widespread social benefits.

The law which has been thus unanimously accepted by the states is a law for democratizing our public school education, by adapting it to the needs of those who must prepare to take up the commoner wage-earning pursuits in agriculture, industry, or commerce. Under the law, also, vocational education is provided in continuation part-time or evening courses for those who have already entered upon some wage earning pursuit. 


\section{Vocational Courses Set Up in the States}

In the past ten months the Federal Board has organized its staff of experts in various lines, and of regional agents for inspection of schools federally aided; has formulated its policies of federal coöperation covering the entire field of vocational education in the states for agriculture, trades and industries, and home management; has approved state plans setting up vocational courses in each of the 48 states, and allotted federal money available under these plans for the fiscal year 1917-18; and has maintained inspection of courses as they have been established in numerous local communities. Federally aided vocational courses have been set up in agriculture in 41 states, in trade and industrial subjects in 32 states, and in home economics in 29 states; 22 states have organized courses in each of these three fields; in 46 states teacher training courses have been organized.

The record of the states in this work is impressive, especially when it is borne in mind that the record covers an initial period of only ten months. In Massachusetts, for example, vocational agriculture is being taught in 19 secondary schools with federal aid; trade and industrial subjects in 36 schools; and home economics in 29 schools. In New York the number of federally aided secondary schools is for agriculture 69, and for trades and industries 40 ; in Pennsylvania, for agriculture 38, for trades and industries 131, and for home economics 69; in California, for agriculture 12, for trades and industries 14, and for home economics 14; in Indiana, for agriculture 37, and for trades and industries 21; in Mississippi, for agriculture 34 , for trades and industries 1 , and for home economics 3. These states are taken at random merely as illustrations of the widespread development of secondary vocational education. The record for other states is equally impressive.

\section{Emergency War Training}

As it happens, the coöperation of the Federal Board during the past ten months has extended far beyond the scope of activities contemplated in the organic law under which the board operates. The administrative machinery built up for undertaking the joint federal and state enterprise of promoting vocational education in the country as a whole has been commandeered for war service,- 
or rather, being immediately available for such service, it has been freely tendered to the war offices and has been by them freely utilized.

Immediately upon its organization, the staff of the Federal Board, in compliance with the general policy approved by the board to render such assistance to the government as it might legitimately do in the emergency of war, began to take on war work. The training of conscripted men for army occupations was conceived to be the sort of vocational education which might most properly be promoted immediately. Under supervision of the Federal Board, war emergency training classes for conscripted men have been organized in the public schools throughout the country. A series of war emergency training courses for army occupations has been prepared, and these courses have been adopted extensively not only for classes organized under the direct supervision of the board, but as well for classes organized by the War Department among men enlisted in the army and for classes conducted on a commercial basis under private civilian control.

The emergency war training bulletins of the Federal Board include emergency training courses in shipbuilding for shipyard workers; mechanical and technical training for conscripted men (Air Division, U. S. Signal Corps); training for motor truck drivers and chauffeurs; for machine shop occupations, blacksmithing, sheet-metal working, and pipe fitting; for electricians, telephone repair men, linesmen, and cable splicers; for gas engine, motor car, and motorcycle repair men; for oxy-acetylene welders; and for airplane mechanics, engine repair men, wood-workers, riggers, and sheet-metal workers. The preparation of these courses and the organization of training classes has been undertaken at the request of, and in coöperation with the Signal Corps and the Quartermaster Corps in the War Department, and the United States Shipping Board.

Growing out of conferences between officials of the Federal Board for Vocational Education and officers of the General Staff, an arrangement was perfected late in October, with the approval of the Secretary of War, for the utilization of the educational facilities of the United States by the Federal Board in coöperation with the War Department for the purpose of training drafted men in various occupations prior to their reporting at the cantonments. An order 
signed by the Adjutant General of the War Department under date of November 3,1917, issued to the commanding generals of all departments and to the chiefs of bureaus, reads in part as follows:

1. The Secretary of War directs that you be informed as follows:

a. The Federal Board for Vocational Education, authorized by act of Congress, February 23, 1917, of which Dr. C. A. Prosser is director, is now organized and is in close coöperation with the vocational schools of the country. This board is prepared to institute a comprehensive system of preliminary training of men of the second and subsequent drafts prior to their reporting at cantonments. . . .

It is the desire of the Secretary of War that the chiefs of bureaus maintain close coöperation with this board, furnishing such information as to number of men desired to be trained, necessary courses, etc. For this purpose the chiefs of bureaus will deal directly with Dr. Prosser.

This work has continued and the War Training Division of the Federal Board reports that on June 13, 1917, 12,000 men had been trained through the Federal Board and state authorities for vocational education, and turned over to services-6,000 in mechanical lines, 5,000 in radio work for the army, navy and mercantile marine, and 1,000 in clerical occupations for Quartermaster Corps work. It estimates that an additional 3,000 men have been trained by private agencies through impetus given to the work by the Federal Board, using Federal Board courses of instruction. Incomplete reports from state vocational authorities for May, return over 6,000 men in training $-3,370$ in radio classes, and 2,508 in mechanical classes, -and it is estimated, on the basis of April returns, that the complete reports for May will show the number in training to be at least 7,500. On June 13, the May reports showed 165 radio classes, operated in 38 states, and 172 mechanical classes in 49 communities in 14 states. Almost daily reports of additional classes being formed were coming in from California, Wisconsin, Missouri, New York and Pennsylvania. Since the May letters were sent out urging the establishment of new classes and the continuance of those in operation, renewed activity has been reported in at least 20 states.

The Federal Board war emergency training bulletins have become standard courses in corps schools, such as the Quartermaster Corps at Camp Joseph E. Johnston, Jacksonville, Florida. Of these bulletins or course outlines some 25,000 copies have been furnished directly or indirectly to the War Department Committee on Education and Special Training for use in its classes, in 
which the number reported in training was 7,086 in April, 10,685 in May, and 26,666 in June. Contracts in force provided for the training of 100,000 men during the current year. This training under military control has been found necessary to provide for the needs of the army, in addition to the training in voluntary classes under the Federal Board.

The esteem in which the Adjutant General's office holds the results of Federal Board training is well indicated by the following order issued to the department commanders under date of May 7th.

Draft men sent division from the May draft and all subsequent drafts who have certificates showing that they have been instructed in certain subjects in schools under the direction of the Federal Board for Vocational Education should be given assignments where they can utilize the training obtained in these schools. You are directed to instruct your personal officers to record on classification card the training each man has received and make assignments accordingly.

McCain.

Classes in shipbuilding occupations have been established in coöperation with the Federal Board in the following states:

North Carolina-Wilmington, evening.

Pennsylvania-Chester, Girard College students.

Ohio-Cleveland, evening classes; Lorain, evening classes.

New York-Port Richmond, Staten Island, evening; Newburgh, evening; Buffalo, evening.

Minnesota-Duluth, evening; part time.

Delaware-Wilmington, evening.

Connecticut-Bridgeport, evening, part time, all day; Housatonic, evening and part time.

California-San Diego, evening classes; Long Beach, evening classes; San Pedro, evening classes; Oakland, evening classes; San Francisco, evening classes; Alameda, evening classes.

Maine-Bath, evening courses.

Oregon-Portland, evening, not confirmed; Astoria, evening, not confirmed.

Washington-Seattle, evening classes.

Bulletin No. 3, Emergency Training in Shipbuilding, is being used in these classes. The following states have appointed agents who will work whole or part time on these classes: Ohio, New Jersey, Texas, Connecticut, Alabama, New York and California.

Vocational Rehabilitation of Men Disabled in the War

Even more absorbing in its appeal to the Federal Board, because of the wide range given to vocational education as a means 
of insuring human welfare, has been the investigation of methods and processes developed in the belligerent countries for vocational rehabilitation of men disabled in the war. Coincidently with its organization the board initiated its inquiries in this field, and it has passed those inquiries continuously during the past ten months. No other agency of the government was prepared to enter this field, and the government naturally turned to the Federal Board for expert service.

The enactment recently by Congress, without a dissenting vote in either house, of the Smith-Sears Act, entrusting to the Federal Board the vitally important work of reëducation and returning to civil employment men disabled in the war, is a recognition of the services of the board during the past ten months in accumulating data relating to rehabilitation work and in devising a scheme of organization for undertaking this work as our men return disabled from service. Here, also, it is provided that there shall be full and complete coöperation. The several government offices concerned with the future welfare of men discharged from the army and navy, including the medical and surgical services of the War Department and the Navy Department, the Bureau of War Risk Insurance in the Treasury, and the labor exchanges in the Department of Labor, together with the Federal Board, will each render service in retaining and returning to civil employment men disabled in the war. The Federal Board will act in an advisory capacity in providing vocational training for men during their convalescence in the military hospitals before their discharge from the army or navy, and will continue such training to finality after discharge, as the civilian agency of rehabilitation and placement in industry.

The time of the members of the board and of the director and his staff has been largely occupied in conferences with representatives of other federal offices, state organizations, casualty insurance companies, chambers of commerce, the Red Cross, and other associations interested in the retraining of men disabled in the war. Out of these conferences the original draft of the Smith-Sears law was formulated. A joint committee of the Senate and House of Representatives conducted public hearings upon the bill, which as finally improved passed both Houses of Congress unanimously. This bill imposes upon the Federal Board new responsibilities which in the immediate future, at least, will be of equal importance with 
those imposed by the organic act creating the board. The publications of the board in this field embrace several bulletins, one of over 300 pages. In preparation for the assumption of the new responsibilities, the director, a member of the board, and representatives of the staff have visited Canadian institutions for retraining disabled men. The secretary of the Canadian Invalided Soldiers' Commission, Mr. T. B. Kidner, who has developed this. work in Canada, appeared before the joint committee in support of the proposed legislation, and he has temporarily undertaken to assist the board in the organization of the work in this country under the Smith-Sears Act.

\section{Opening a Larger Field of Usefulness}

A still larger field of usefulness is opened up to the Federal Board and for vocational education in general, since it is in mind that the experience gained in the work of reëducating men disabled in the war, and the administrative machinery and expert service developed for this work shall all be utilized after the war for rehabilitating the victims of industry, as well as the thousands of natural cripples who in the past have been abandoned to hopeless indigence.

The Federal Board has thus undertaken to promote vocational education in the states, and so to promote the development of such education in the present emergency as to provide for the special needs of the war and of men disabled in the war. In each of these fields it has appeared as an administrative agency of coördination and coöperation, and it has conceived a vision of usefulness in the future which it believes to be in a fair way of realization.

These are the large aspects of the Federal Board's operation and policies during the brief period that comprehends its own organization, its entrance into entirely new fields of vocational education, its extension of service into each of the 48 states, and its preparation for the assumption of new responsibilities in rehabilitating the disabled and crippled.

A survey of the past ten months warrants the conclusion that the program of vocational education is in a fair way of being realized even beyond the most sanguine hopes of those who have in the past participated in formulating that program. Education in the public schools is rapidly being democratized and adapted to the needs of our citizenship. In realizing this program the states have 
responded splendidly. State education authorities also responded splendidly to the appeal of the federal government, through the Federal Board, to demonstrate the practical utility of vocational education in the exacting emergency of war. The institutions providing vocational training for conscripted men have stood the acid test of devising schemes of training to meet the special requirements of waging war. This demonstration of social service in a great emergency will stand to the credit of vocational education after the war is won as fulfilling the highest ideals of its advocates, and it may confidently be anticipated that the achievements in the future, when the community returns to its peaceful pursuits, will even exceed those rendered in war time.

\title{
HOUSING FOR WAR WORKERS ENGAGED ON ARMY AND NAVY CONTRACTS
}

\author{
By JAMES Ford, \\ Manager, Home Registration and Information Division, \\ Bureau Industrial Housing and Transportation.
}

The problem of housing munition workers was serious in America prior to our entrance in the war. In Bridgeport. and various other cities filling war orders for our Allies, there was considerable pressure of population and a shortage of accommodation. This shortage became much more serious and this whole problem more widespread, after our entrance in the war. Building materials, labor and capital, were difficult to secure, prices of both materials and labor high, and private construction became considerably reduced even when the need of construction was rapidly increasing. Construction by the federal government was therefore imperative.

It was quickly recognized that house building was an important part of the war program; it was seen that it would be impossible to get an adequate labor supply or to hold it, unless the workmen were properly housed in convenient, sanitary dwellings accessible to their work shops, and offered at a rental which they could afford to pay. An allotment of $\$ 50,000,000$ was made by Congress in March, 1918, to provide for building houses for workers in the shipyards. Subsequently $\$ 25,000,000$ was added to the fund; this $\$ 75,000,000$ is 